\title{
PRELIMINARY OBSERVATIONS ON SCALES AND THEIR MODE OF ORIGIN IN CHRYSOCHROMULINA POLYLEPIS SP.NOV.
}

\author{
By Irene Manton, F.R.S. \\ Botany Department, Leeds University \\ AND Mary PARKe, D.Sc. \\ The Plymouth Laboratory
}

(With total of 28 Figures in text and on Plates I-VIII)

Scale characters feature so predominantly in diagnoses of species of Chrysochromulina that information on the mode of production has been sought for some time. That this has proved difficult to obtain has been mainly due to the extreme transparency of scales in section which makes them virtually unidentifiable in an immature condition. Two recent investigations on other genera have, however, shown clearly that a flagellate containing chlorophyll $b$, Micromonas squamata Manton \& Parke, 1960, produces its scales in vesicles within the body and not directly from the body surface, and that a colourless member of the Chrysophyceae, Paraphysomonas vestita, does the same (Manton \& Leedale, I96I $a$ ). A little evidence pointing in this direction has been encountered from time to time among the seven species of Chrysochromulina for which sections have now been published (see especially statements on C. chiton, by Parke, Manton \& Clarke, I958, C. strobilus by Parke, Manton \& Clarke, 1959, and C. minor, by Manton \& Leedale, I96I c) but the importance of our present species is that here for the first time there is sufficient evidence to be conclusive.

That the species happens to be a new one which has also to be described and named is fortuitous and in a sense an inconvenience, which will temporarily prevent full exploration of every relevant aspect of its structure and development. We have, however, resisted the temptation to separate entirely the taxonomic description from the anatomical inquiry because some knowledge of the morphology is equally necessary for both. We propose however to emphasize the electron-microscopical facts most directly required for the preliminary interpretation of the anatomy by giving these first, reserving the taxonomic description and detailed light-microscopy until the end.

All the technical details are the same as those used before. As on previous occasions we wish to express our thanks to members of staff of the two laboratories, more especially to $\mathrm{Mr} \mathrm{K}$. Oates for making the shadowcast 
preparations used in the first four plates, to Miss I. Adams for assistance in the routine examination of samples, and to Miss D. Ballantine for testing this organism for its possible toxicity to fish. We are indebted to Dr T. Christensen of Copenhagen for turning our specific description into Latin and for suggesting the specific name polylepis.

\section{GENERAL MORPHOLOGY}

Pl. I will sufficiently introduce the more salient features of the monad itself. It is a species of moderate size with a relatively short haptonema. The body is covered with scales which fall off as soon as a specimen is dried. As may be seen from Figs. 3 and 4 the scales from one cell are unusually varied, no less than four different types being habitually found together. Other structural details of importance for the anatomical findings are the relatively large size and coarse texture of several of the scale types, together with a suggestion of

\section{Explanation of Plates I-IV}

Chrysochromulina polylepis sp.nov.

I

Figs. I, 2. Two cells killed with iodine and photographed under dark ground illumination with the light microscope. $\times$ rooo.

Fig. 3. A cell dried and shadow-cast showing the coiled haptonema between the bases of the two flagella and a varied array of scales close to the cell body. Electron micrograph B 3446, $\times$ ro,000.

Fig. 4. An uncoiled haptonema and the bases of two flagella, the tip of a flagellum as an inset. Two large elongated scales crossing the appendages (left); some large rounded scales in other parts of the field. Micrographs B 4374 and B $3443, \times 10,000$.

\section{II}

Fig. 5. Group of detached large rounded scales seen from the outer side, with their rims projecting upwards; two other types of small scales also present. Micrographs B 4370 , $\times 30,000$.

Fig. 6. Single small elongated scale seen from the lower face (for upper face see fig. 5, centre). Micrograph B 4370, × 30,000.

Fig. 7. Group of large rounded scales and three small rounded scales, all with their lower faces exposed. Micrograph B 4364, ×30,000.

Fig. 8. Two small rounded scales, one damaged and showing the details of the rim on the side facing the plate, the other showing the opposite surface, i.e. with the rim outwards. Micrograph B 4364, × 30,000.

III

Fig. 9. Group of small rounded scales and one large one; the latter seen from the lower side, the others showing both surfaces (compare with figs. 7 and 8). Micrograph $\mathrm{B}_{3438}$, $\times 30,000$.

Fig. Io. One large elongated scale with a forked appendage and a group of small elongated scales all showing their lower surfaces (for other view see fig. 5 centre). Micrograph B 2692, $\times 30,000$.

IV

Fig. Ii. Two large rounded scales and one small rounded scale, all seen from the lower side. Micrograph B $2675, \times 50,000$. 


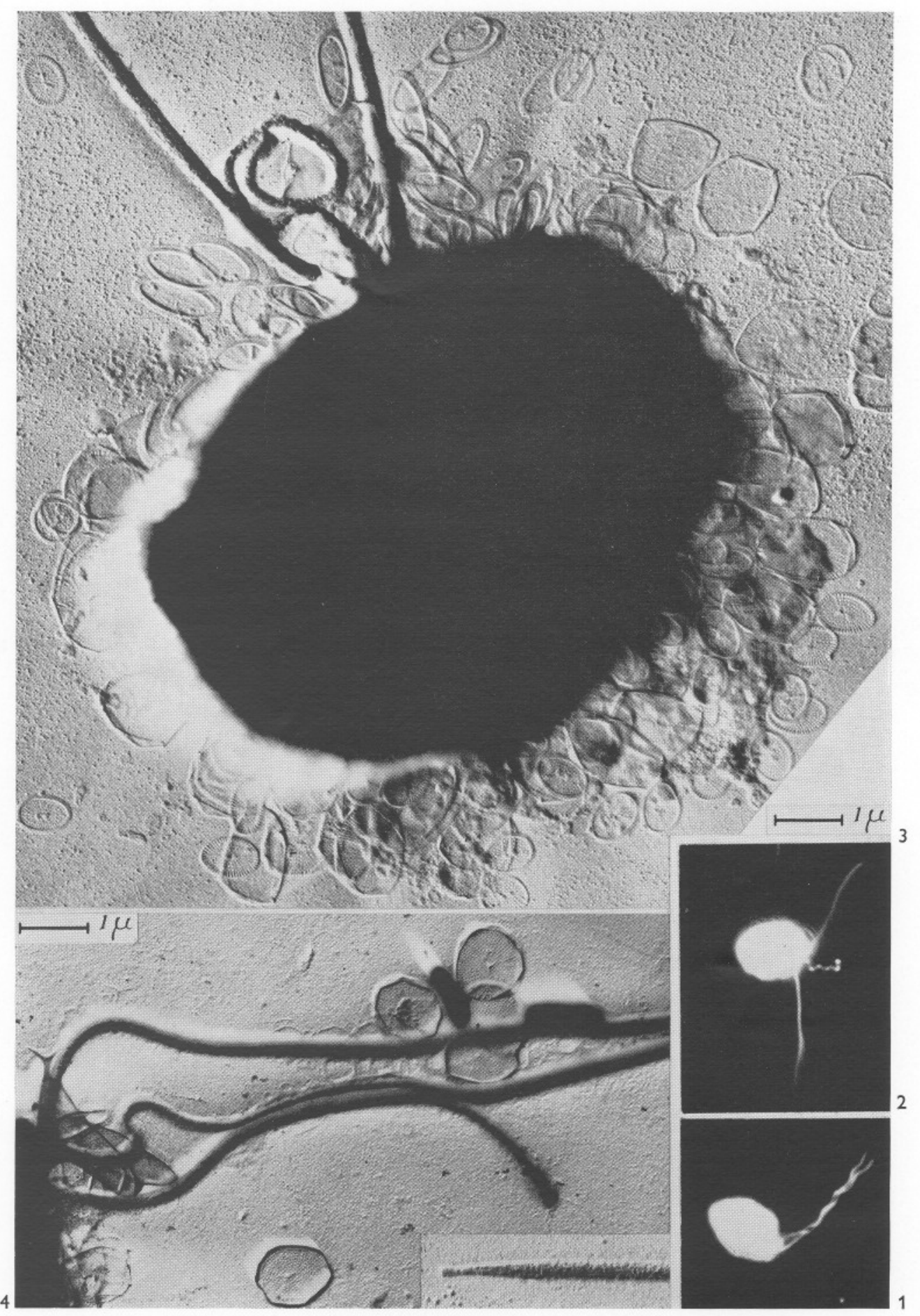

(Facing p. 566) 


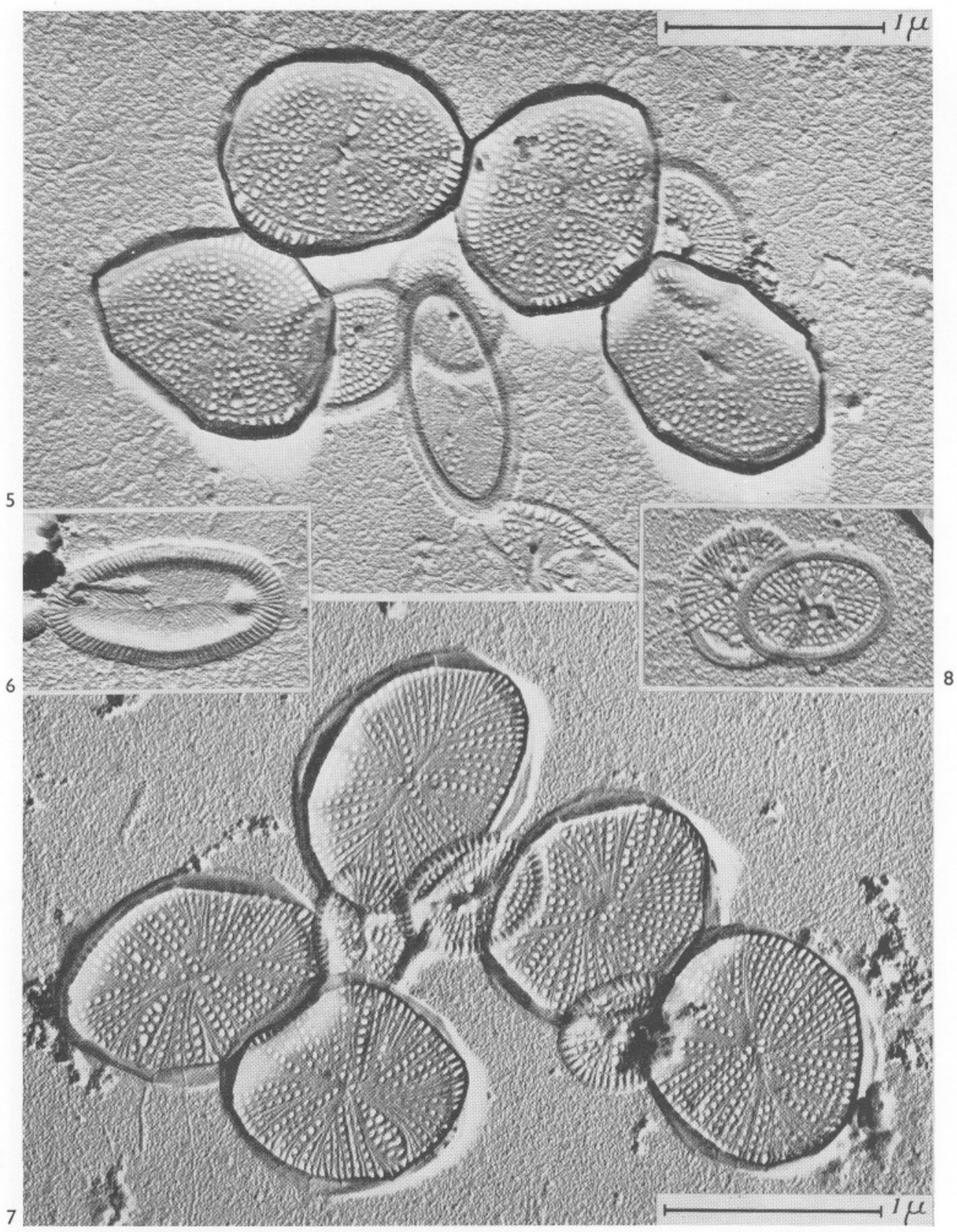



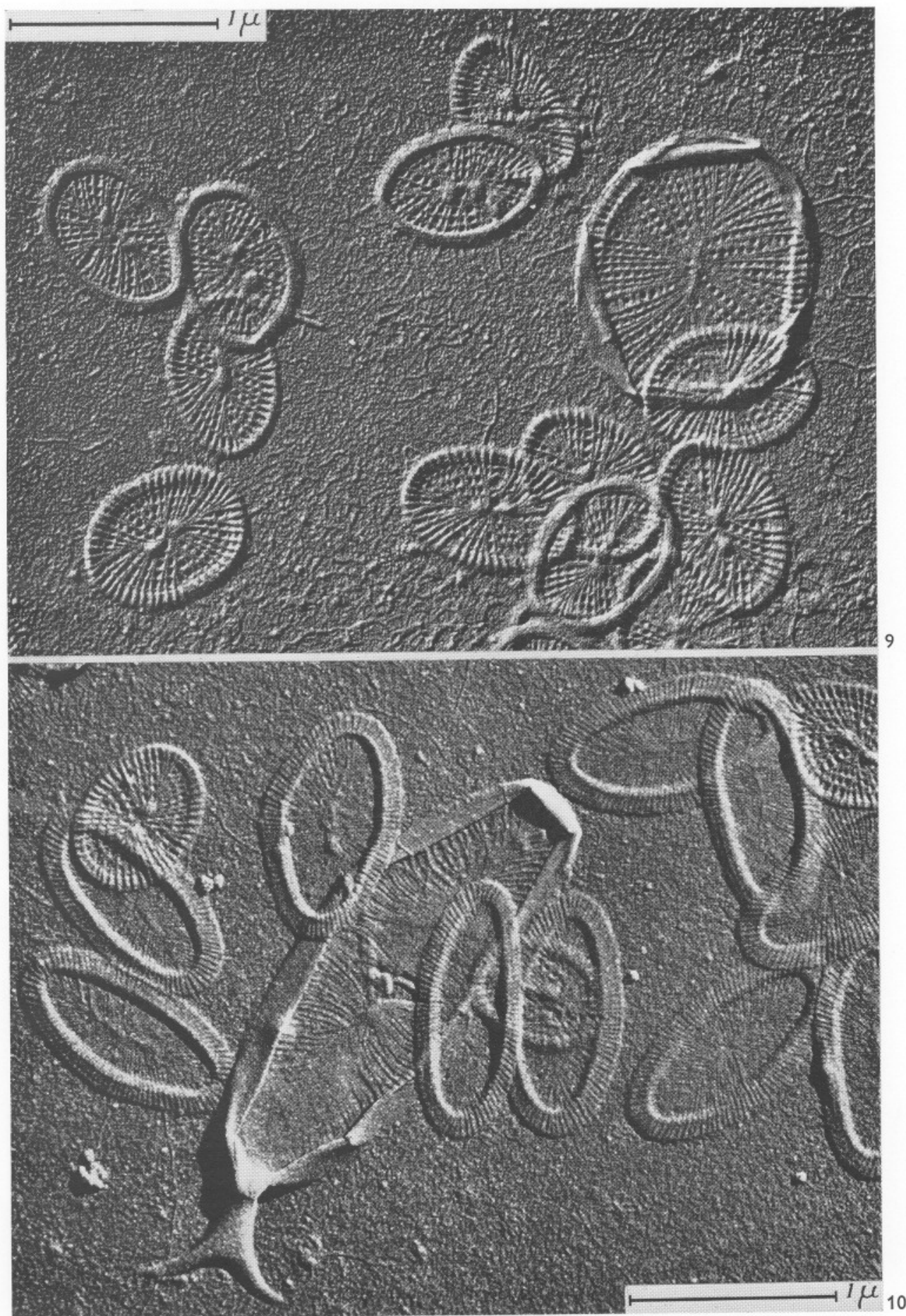


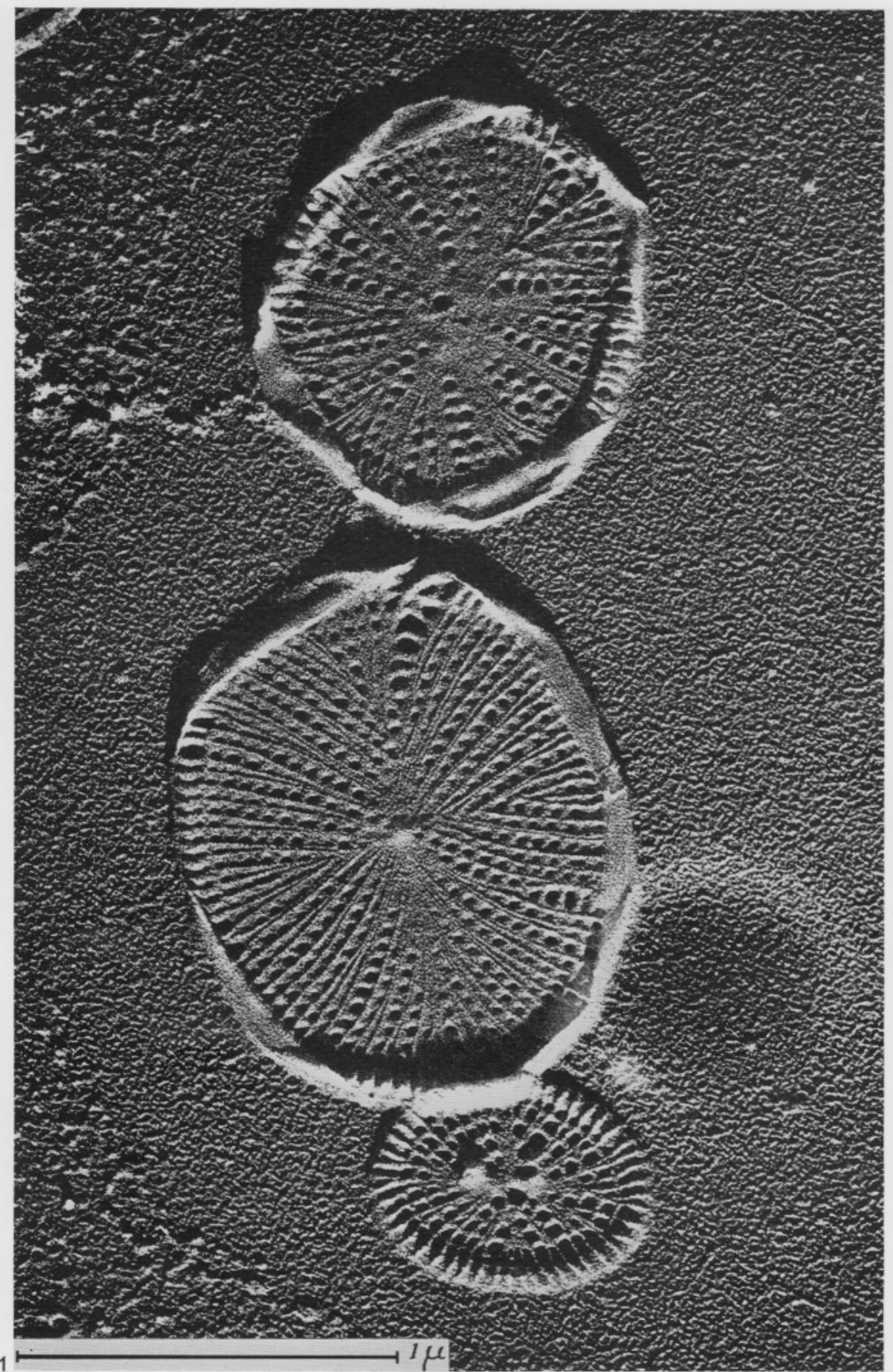


some degree of mineralization in all of them. The chemical basis for the latter has not yet been explicitly studied, but the scales in this species are undoubtedly somewhat more opaque to electrons than is usual in species of Chrysochromulina, an attribute which is even more important in sections than it is in whole mounts.

The various scale types are present in characteristic but significantly different relative numbers. The largest are elongated plates present singly or at most as two or three near the bases of the flagella (Fig. 4 left). The next largest are roughly isodiametric plates (Fig. 4 right) visible on all sides of the body in Fig. 3, and appearing somewhat angular at this low power owing to the configurations of the collapsed rims. A group of small elongated plates is commonly present near the flagellar bases (Fig. 3 top left), estimated numbers in a few individual cells being 20-30. The fourth type (Fig. 3 right) are small oval plates with two central bulbosities; their numbers can scarcely be estimated near intact cells since they are commonly overlaid by the larger plates associated with them but, when counts are made on groups of isolated

TABLE 1. FREQUENCY OF DIFFERENT SCALE TYPES IN TWO SAMPLES OF TEN DISMEMBERED CELLS

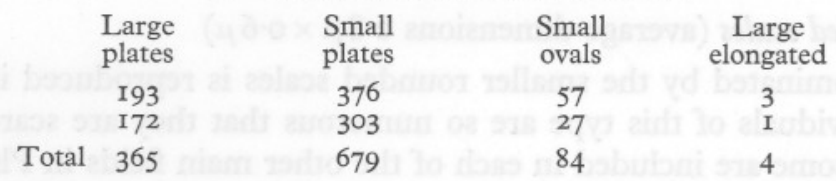

scales encountered at sites from which cell bodies have fallen away, they are found to be nearly twice as numerous as the large plates. Some actual counts are summarized in Table I, from which it may be calculated that for one of the large elongated plates there were twenty-one of the small elongated plates, ninety-one of the large rounded plates and 170 of the small rounded plates. These numerical relations suggest that the large and small rounded scales may just possibly represent two superposed layers on part or all of the body surface while both types of elongated plates seem to be restricted to a circumscribed zone near the flagellar bases.

\section{MORPHOLOGY OF INDIVIDUAL SCALES}

While scales in association with bodies provide the best and indeed the only electron microscopical evidence for scale arrangement, the finer details of their structure can far more conveniently be ascertained from scales lying loose about the field, which they do in great numbers. Some characteristic examples are reproduced in Pls. II and III, the fields having been selected to show not only the range of scale types but also the differences of pattern on the two surfaces. Final verification of which surface lies outwards relative to the subtending body is easily provided from sections, except for the large 
elongated scales (Fig. I0), which seem likely to be attached quite differently. It will therefore be sufficient in the account which follows to designate outer and inner faces as simple statements without elaborating individually the evidence for relative position.

\section{Large rounded scales (average dimensions $\mathrm{I} \cdot 4 \mu \times \mathrm{I} \cdot 2 \mu$ )}

The surface pattern of these scales is very similar on the two faces which can, however, be distinguished if attention is paid to the condition of the relatively wide rim. In profile the scales are saucer-shaped with the rim arranged at right angles to the plate and projecting outwards. Fig. 5 shows this surface and Fig. 7 the undersurface; in the former the rims are still erect while in the latter the rims are disarranged as the plates press down upon them on drying, causing the somewhat angular appearance detected under low power (Fig. 3). The material of the rim is patternless. The plate is, however, a meshwork with holes, probably arranged in two layers (see especially Fig. 7 lower centre) but with some of the structure apparently obliterated by overlaid amorphous material, especially on the upper surface, but with a pattern of ribbing more clearly visible on the lower surface.

\section{Small rounded scales (average dimensions $0.8 \mu \times 0.6 \mu$ )}

A field dominated by the smaller rounded scales is reproduced in Fig. 9, though individuals of this type are so numerous that they are scarcely ever absent and some are included in each of the other main fields in Pls. II-IV. The plate consists of a loose meshwork with probably less solid matter per unit area than in the large rounded scales. The ribbed pattern on the lower face is very distinct, while the upper face (Figs. 8 and 9) shows a patternless rim pressed closely against it. The two central bulbosities are generally visible on both surfaces though the evidence from sections indicates that they actually project upon the upper surface.

\section{Small elongated scales (average dimensions $\mathrm{I} \cdot 2 \mu \times 0.6 \mu$ )}

Scales of this type may occasionally dominate a field (Fig. Io) though they are more often encountered in small numbers among the others. The two surfaces may be seen in Fig. 5 centre and Fig. 6 respectively, the upper surface (Fig. 5) being relatively patternless and the lower surface (Fig. 6) strongly ridged. The rim is wider than in the small rounded scales but like them is strongly flexed towards the upper surface of the plate. When seen in profile in sections there is reason to think that the plate is somewhat convex when seen from above.

\section{Large elongated scales (average dimensions $2.5 \mu \times 0.9 \mu$ )} These scales are relatively scarce and there is as yet no means of
ascertaining the precise manner in which they are borne on the cell. They are 
clearly plates with rims and with surface markings recalling those of some of the other scale types. It is probable that there are minor differences on the two faces since some scales show signs of a meshwork with holes more clearly than in the one reproduced in Fig. I0. A more important distinguishing character is the forked projection present in a characteristic position at one end. This type of differentiation between the two ends suggests that these scales are attached to the cell terminally and do not lie flat, but whether the forked end represents a stalk or a distal spine is unknown.

Before leaving the subject of scale morphology it is perhaps helpful to draw attention to Pl. IV which has been inserted to facilitate comparison with the scales of the type-species of the genus (C. parva Lackey) which have recently been illustrated at the higher magnification of 50,000 (Parke, Lund \& Manton, 1962).

\section{MICROANATOMY OF THE CELL}

The distribution and character of the major organelles within the cell is at first sight unremarkable. Figs. I2 and I3, P1. V, show two complete sections at relatively low magnifications, both cut near to the flagellar bases though only Fig. I3 actually includes part of a base (top left). There is a normal nucleus with nucleoli. The chromatophores have pyrenoids of the immersed type (Fig. 13) while the mitochondria and Golgi bodies seem normal. Part of a Golgi body is shown more highly magnified in Fig. I6, Pl. V, with a few dense-walled vesicles nearby which have probably originated by abstriction from the edges of the Golgi cisternae as recently encountered in Paraphysomonas vestita (see Manton \& Leedale, I96I $a$ ) and $C$. parva (see Parke, Lund \& Manton, 1962). The haptonema also is normal and observations on it are restricted here to one transverse section (Fig. I5) to show the ring of seven fibres within the usual three concentric membranes (the outer membrane here distended as a fixation artifact) and one longitudinal section through the base (Fig. I4) to show the penetration of the central fibres, but not the membranes, into the cell.

At higher magnifications evidence on the origin of scales is at once revealed (Pls. VI and VII). Fig. I7 shows part of the cell of Fig. I2 in an adjacent section. At the top of the field, a large vesicle below the cell surface contains an unmistakable section of one of the small rounded scales with central bulbosity and inflexed rim (cf. Fig. 9, P1. III). Guided by this it becomes easy to recognize a fragment of scale in each of two adjacent large vesicles near the cell surface in Fig. I2. At a deeper level (arrows in Fig. I7) parts of at least two other scales are detectable the larger of which cannot be other than part of a large plate scale. A scale of this type seen in face view is present inside a vesicle in Fig. I8 and very near the cell surface in Fig. 19. Multiplying the evidence still further we have a group of scale-bearing vesicles just below the flagellar insertions in Fig. $20 a$ and $20 b$, parts of at least four 
scales being represented among the two adjacent sections. Finally Fig. 2I permits a general comparison to be made between a scale outside the cell (top left) and two scales in different internal vesicles, the upper one of which almost certainly represents one of the small elongated plates.

It would not have been difficult to multiply such examples still further but it is perhaps sufficient to have shown parts of five different cells.

\section{THE DIURNAL RHYTHM}

The ease with which the observations contained in Pls. VI and VII had been obtained, compared with the almost total failure in previous investigations with other species, prompted an enquiry into whether or not a diurnal rhythm

\section{Explanation of Plates V-VIII \\ Chrysochromulina polylepis sp.nov. \\ V}

Fig. I2. General view of a section showing the nucleus $(N)$, mitochondria $(m)$, a Golgi body $(g)$, plastids $(P)$, besides vesicles and granular protoplasm; afternoon fixation. Micrograph B $3232, \times 18,000$.

Fig. 13. Another section from the same material as fig. I 2 to show the immersed pyrenoid (left) and a conspicuous group of vesicles between the nucleus (right) and the cell surface with traces of flagellar bases. Micrograph B 2920, $\times 10,000$.

Fig. I4. Base of a haptonema $(H)$ entering a cell. Micrograph B $3290, \times 25,000$.

Fig. I5. Transverse section of a haptonema showing three concentric membranes and seven internal fibres. Micrograph B3078, ×60,000.

Fig. I6. Details of the Golgi body in the specimen of fig. I2 from another section, the nucleus $(N)$ on the left. Micrograph B $3430, \times 40,000$.

\section{VI}

Fig. 17. Part of the surface of another section of the cell of fig. I2 showing internal scales (arrows); other labels as in fig. 12. Micrograph $\mathrm{B}_{3238}, \times 30,000$.

Fig. I8. Section exposing surface of a large rounded scale in face view within a vesicle situated between two plastid lobes. Micrograph B 2714, $\times 20,000$.

Fig. 19. Part of another specimen showing profiles of internal plate-scales very near the surface. Micrograph B2758, × 30,000.

\section{VII}

Fig. 20a, $b$. Two successive sections through a group of scale-bearing vesicles near the flagellar bases and between plastid lobes $(P)$ and mitochondria $(m)$; arrows in fig. $20 a$ point to fragments of scales clearly recognizable as such in the original prints. Micrographs $\mathrm{B} 2806$ and $\mathrm{B} 2805, \times 25,000$.

Fig. 21. Group of scale-bearing vesicles near the surface of another cell. Micrograph B 2932, $\times 40,000$.

VIII

Fig. 22. Part of a section from the 4 a.m. material showing some special features in the region of cytoplasm delimited by the cell surface, the nucleus $(N)$ and the two plastids $(P)$ : one residual scale-bearing vesicle present near the surface (long arrow); beneath this a large curved Golgi body gorged with internal secretion (broad arrow) at one end but still abstricting small dense-walled vesicles at the other end (small arrows). Micrograph B 3286, $\times 30,000$. 


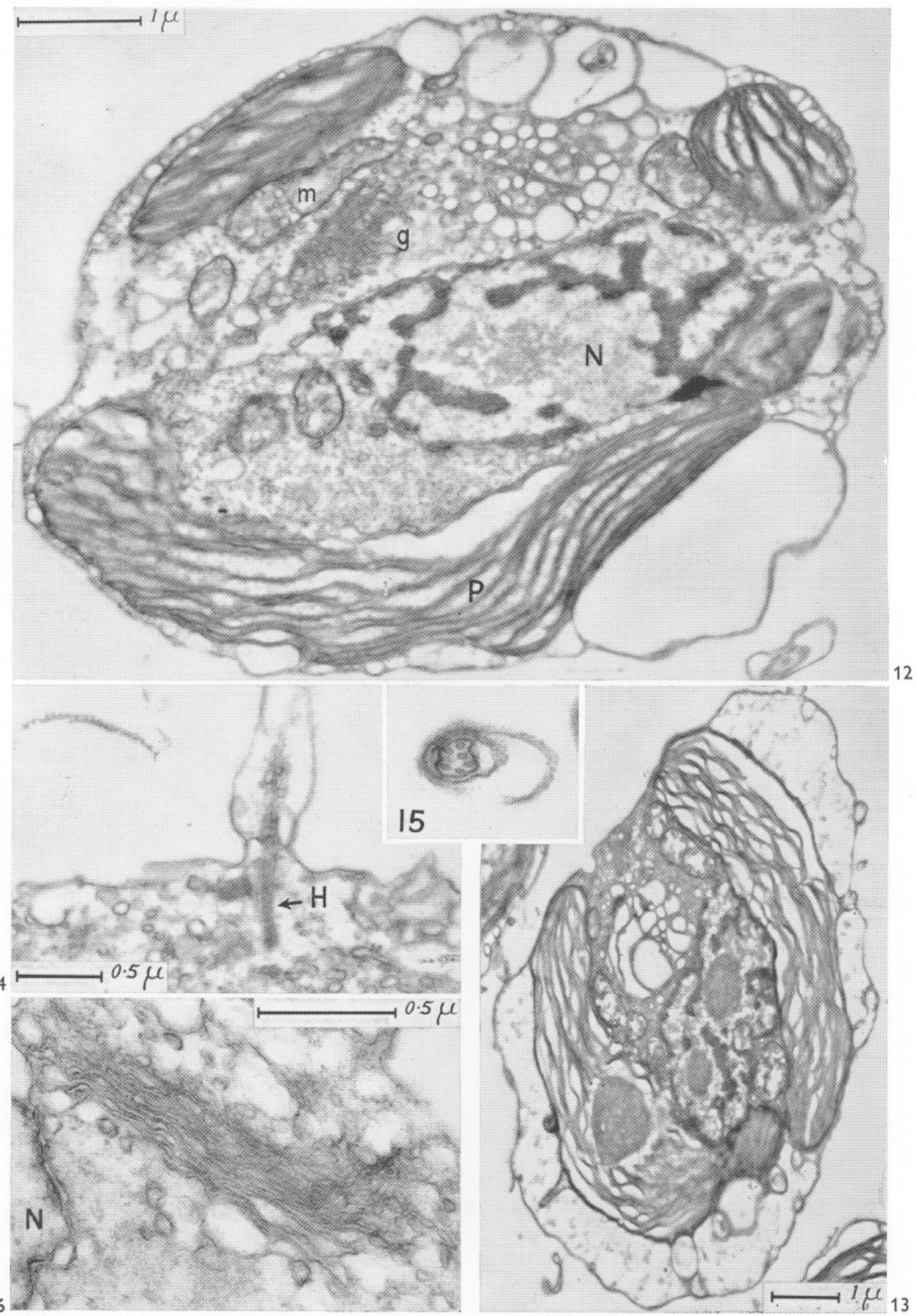

(Facing p. 570) 


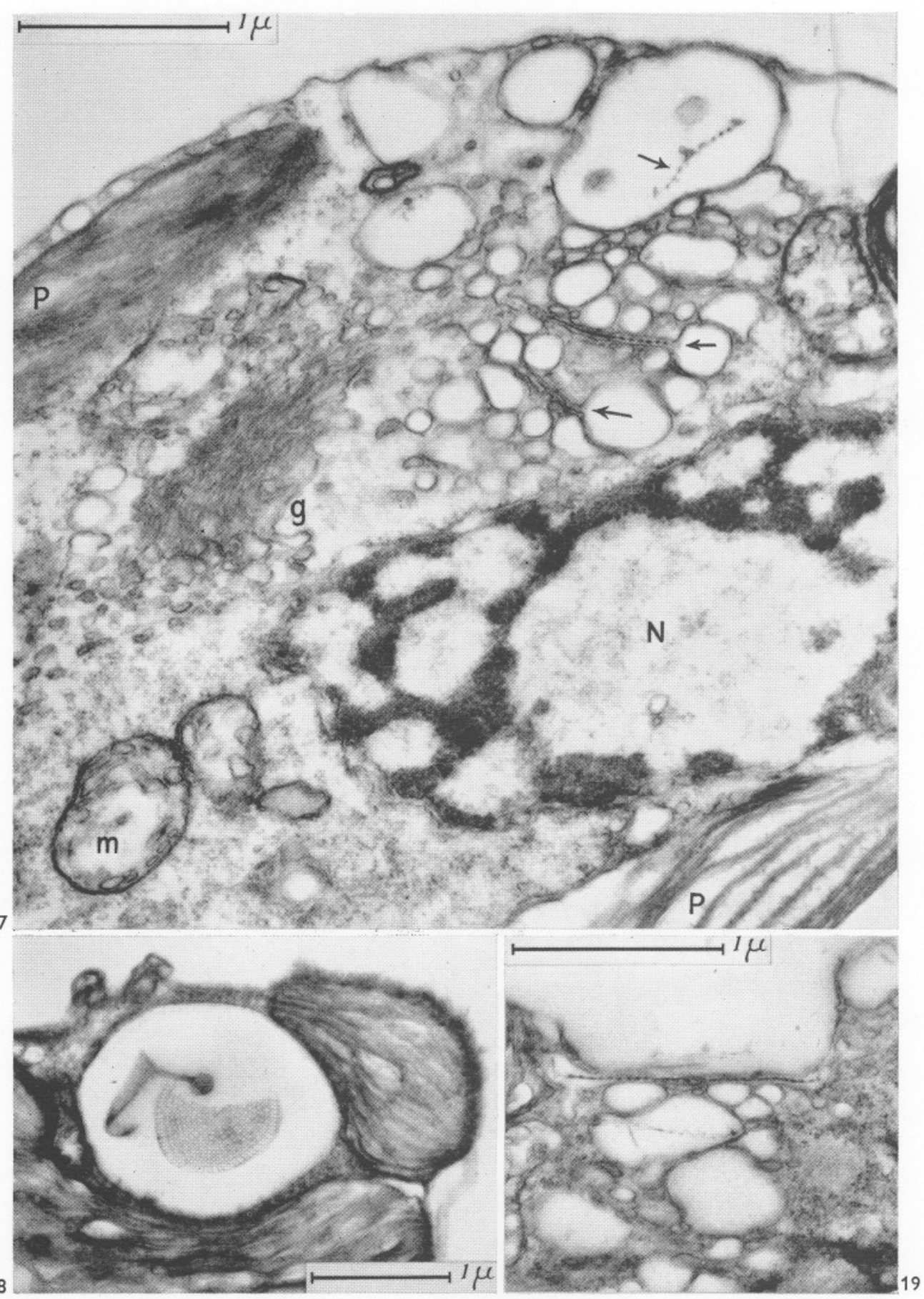



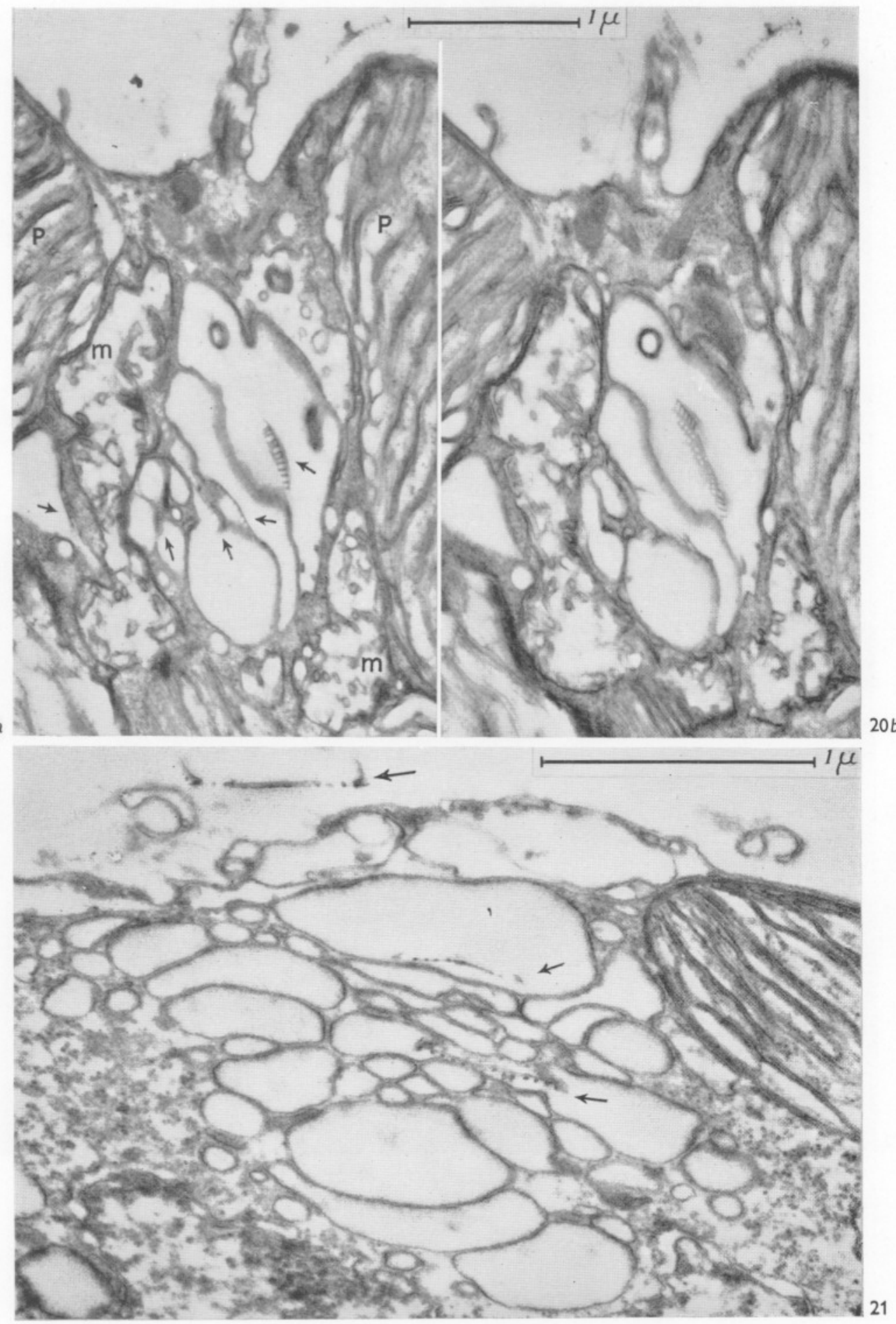


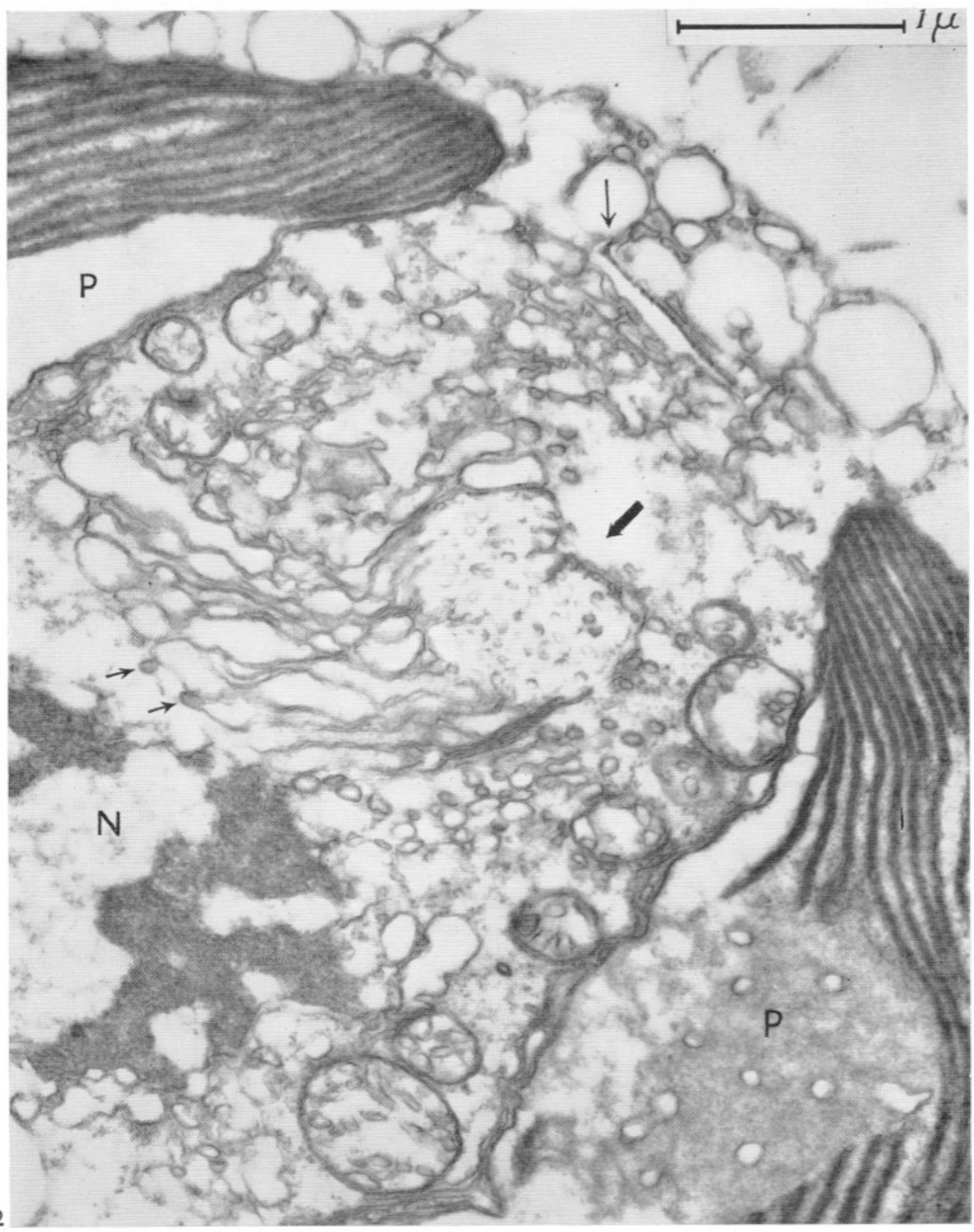


might exist here which by chance had coincided favourably with the time of day at which the material had been fixed. This was in any case known to have been somewhat unusual since fixation in the morning has generally been preferred whereas this particular species had been fixed first at 3.15 p.m. British summer time on Io April I96I. To test this possibility fixations were taken at approximately $6 \mathrm{~h}$ intervals during $24 \mathrm{~h}$. The experiment was begun at I I a.m. on 20 May, continued at 4 p.m. and Io p.m. on the same day and ended at 4.30 a.m. on 2I May. Under the conditions of indoor culture with additional artificial light during the daytime only, these fixation times represented two in daylight (II a.m. and 4 p.m.) and two in darkness, the earlier of the dark fixations (IO p.m.) being dark with respect to the position of the culture flask but dusk from the point of view of an investigator moving about the laboratory. The dawn fixation (4.30 a.m.) was similar. The middle of the dark period was not sampled.

Strong evidence in favour of a diurnal rhythm was at once obtained when these fixations were cut, the greatest contrast being between the 4 p.m. and the $4.30 \mathrm{a} . \mathrm{m}$. material. The former repeated exactly the experience of 3.I 5 p.m. of a month earlier with respect to scale production and Figs. I2-I7 were indeed obtained from it, but at night internal scale production became progressively less conspicuous until only an occasional single scale here and there in a section in a population could be detected. Mitotic stages, on the other hand, became conspicuous at $4.30 \mathrm{a} . \mathrm{m}$., no less than 5 metaphases being encountered in a few preparations cut from one block. This contrasts with exactly one metaphase recently illustrated in C. brevifilum (Manton, I96I) as the first recognizable mitotic stage recorded among seven species for which sections have been reproduced. No metaphases were seen in any of the other three fixations in the $24 \mathrm{~h}$ series.

At least as important as the mitotic stages were the changes exhibited by the Golgi apparatus. These were of several kinds occurring concurrently and reference to Fig. 22, P1. VIII will exemplify them in a general way. One end of the organ (right in Fig. 22) appears gorged as if with an impounded internal secretion of the type previously referred to as ' peculiar Golgi' (Parke, Manton \& Clarke, 1959; Manton \& Leedale, 196I $b, c)$. The end so affected is characteristically that directed towards the cell surface and often demonstrably close to the place of entry of the flagellar bases. At the other end, small dense-walled vesicles are still being abstricted from the edges of the Golgi cisternae (arrows near the nucleus in Fig. 22) though the cisternae themselves are also becoming generally distended with contents and curved.

In addition many cells exhibited double Golgi bodies in relative attitudes suggesting an origin by division from a single body, and in many such cells both Golgi bodies possessed the 'peculiar' internal secretion and strongly curved cisternae.

Before leaving Fig. 22 it is profitable to notice the large plate-scale in the 
cytoplasm near to the cell surface which exemplifies the description given above of a belated remnant of the previous day's scale production lingering into the late night hours in an occasional cell. In a majority of cells, and especially in those with still more strongly curved Golgi bodies than that of Fig. 22, scale production seemed to have ceased.

\section{INTERPRETATION OF THE MICROANATOMY}

While it will clearly be necessary to obtain many more details regarding processes such as division of the Golgi bodies in relation to other events in the cell before full interpretation of the observations will be possible, we are already in possession of much new information of the greatest value. It seems certain that in this organism manufacture of scales within vesicles inside the cell is the normal method of producing them and that the greater number encountered in this position by day compared with night may be connected with a growth cycle limiting mitotic stages to the dark hours and cytokinesis to the daylight hours. It seems reasonable to suppose that during the act of nuclear division manufacture of scales may be at a minimum though it must not be forgotten that the growth cycle involves replication of many other cell components besides the nucleus (e.g. chromatophores, Golgi bodies, mitochondria, flagella, haptonemata) the timing of which must also be directly or indirectly geared to the mitotic cycle and all must be taken into account if an accurate time-scale for the whole process is to be prepared.

Some of the changes in the Golgi bodies occurring during darkness, notably the spectacular accumulation of the 'peculiar' secretion seems to indicate that this hitherto unexplained deviation from normal Golgi structure is in fact a developmental stage by which in this species something which is utilized by day is manufactured, or at least permitted to accumulate, at night. That this material might be utilized in manufacturing some component which must be replicated during cytokinesis is inherently probable, though what this component is we have as yet no direct evidence.

This apart, the great morphological difference between the 'peculiar' secretion and the small dense-walled vesicles abstricted from other edges of the Golgi cisternae suggests very strongly that metabolites in more than one form and probably of more than one kind are being secreted into the cytoplasm. The Golgi body is thus clearly an organ of major metabolic significance even if the morphogenetic implications had been lacking.

\section{FURTHER OBSERVATIONS WITH THE LIGHT MICROSCOPE}

This organism shows a very marked phototactic response and in culture can reach a density of $\frac{3}{4}$ million cells per $\mathrm{ml}$. So far no cells lacking chromatophores have been observed in our cultures. 
During swimming the flagellar pole can be foremost with the flagella sweeping outwards and backwards down the sides of the body or, as in many other species of the genus (Parke et al. 1955, 1956, 1958, 1959), the flagella and flagellar pole may be directed backwards; in both positions the haptonema can be extended or coiled. Movement is fairly rapid, the cells swimming only for short distances in one direction, after which they either rapidly change the position of the flagella and move off in the opposite direction (Figs. 23, 24) or curl the ends of the flagella to stop movement (Fig. 26). When moving with the flagellar pole foremost the body rotates with a characteristic lop-sided movement with the tip of one flagellum farther behind the body than the other (Figs. 23, 25). As cells rotate slowly in this manner bands, made up of what appear to be the large rounded scales, can be distinguished on the body in the positions illustrated in Figs. 24-26. A gliding movement somewhat similar to that described for $C$. chiton (Parke et al. 1958) also occurs, but in our present species the gliding can take place when the flagellar pole is in front of, as well as behind, the body.

A further characteristic of this organism is its capacity for remaining in one position for long periods, attached by the tip of its haptonema and with the flagella gently undulating. The haptonema can show all degrees of extension from a Prymnesium-like condition with only the distal tip visible (Fig. 25) to a fully extended condition in which the tip is frequently curved over like a shepherd's crook (Fig. 23).

Phagotrophy is of common occurrence, the cells ingesting organisms or graphite (Fig. 23) up to $3 \mu$ in diameter. Red-brown masses of unknown origin and composition, from $2-3 \mu$ in diameter, are sometimes present in the body towards the non-flagellar pole and resemble very closely bodies of similar colour noted in the coccolithophorid, Cricosphaera carterae (B. \& F.) Braarud. Frequently these masses are found free in the medium and on one occasion a mass was seen discharged from the non-flagellar pole.

Chrysose (leucosin) may be present as a single large globule up to $4.5 \mu$ in diameter or as two or more small masses lying usually towards the nonflagellar pole. The nucleus, very rarely observed in the living cell since it is masked by the dense chromatophores, is ovoid, from $2-3 \mu$ long and lies nearly centrally in the body towards the flagellar pole. There are usually one to four quite conspicuous lipid globules present, lying close to the inner faces of the chromatophores and measuring from 0.5 to $\mathrm{I} \cdot 0 \mu$ in diameter. Two or four bodies about I $\mu$ and a number of smaller granules stain with Janus green and are probably mitochondria. Another body, probably Golgi, also stains faintly with Janus green. The muciferous organelles (Fig. 24), about $0.5 \mu$ in diameter, discharge their contents very readily, in a manner exactly similar to that described for C. ericina (Parke et al. 1956, p. 394).

Fission stages can be observed more frequently from midday to early evening (Figs. 27, 28). The newly formed daughter-cells, usually of about 


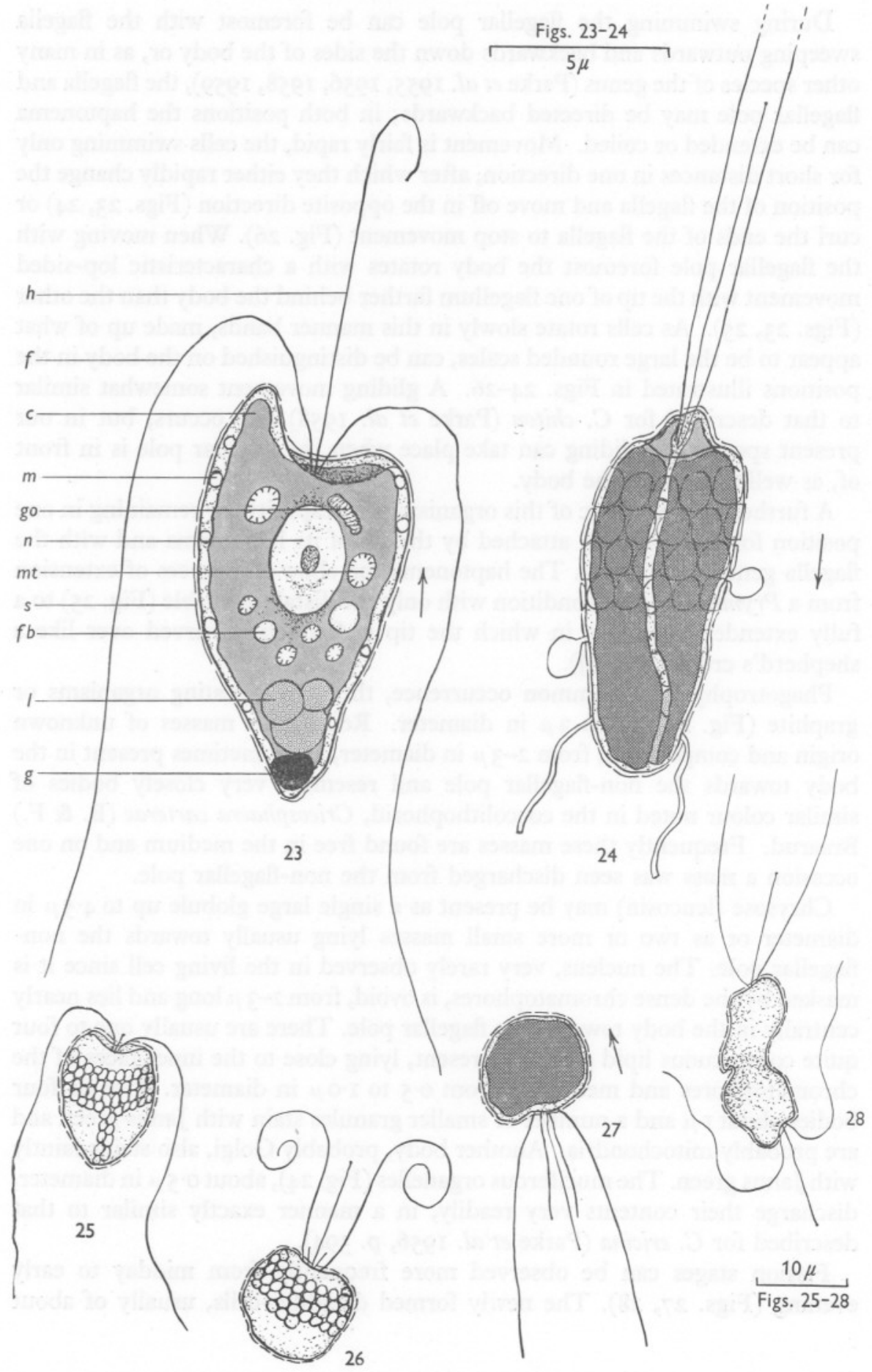

Text-figs. 23-28. For legends see opposite page. 
equal size, measure from $6 \times 5$ to $7 \cdot 5 \times 6 \mu$. The daughter-flagella arise between the parent-flagella, the new flagella and haptonema being formed before the actual fission of the body starts. On several occasions during examination under dark field, two appendages, $2 \mu$ long, have been observed at the flagellar pole arising between the long flagella (Fig. 26). It could not be decided whether these structures were the large stalked scales (Fig. Io, Pl. III) or extremely young daughter-flagella.

Although checking for non-motile stages has been made repeatedly on cultures of different ages, on one occasion only (in a 3-month-old culture) has a possible non-motile phase been detected. The stage observed was a pseudo-filament of 4 cells, from which the contents had been released. This suggests that in this species a pseudo-filament, similar to that found in some coccolithophorids (Parke, I96I) may be produced.

\section{FORMAL TAXONOMIC DESCRIPTION}

\section{Chrysochromulina polylepis sp. nov.}

Motile cells showing some metaboly; generally ovoid but sometimes subspheroidal, with flagellar pole obliquely truncate and depressed centrally to produce a groove across one axis; larger individuals conspicuously flattened and with a protruding lip (or hump) on one side of the flagellar pole; $6-\mathrm{I} 2 \mu$ in length by $5-9 \mu$ in breadth. The appendages arising close together centrally from the depression; the flagella subequal, or of equal length, very occasionally unequal, homodynamic, 2-3 times body length,

\section{Legends to Text-figs. $23-28$ \\ Chrysochromulina polylepis sp.nov.}

(Figs. 23-24, $\times 5000$; Figs. 25-28, $\times 1250$ )

Fig. 23. Individual with flagella and haptonema in the position characteristic for the species when swimming with flagellar pole foremost. $c$, Chromatophore of lower face only illustrated so that body contents are not obscured by second chromatophore; $f$, flagellum; $f b$, lipid globule; $g$, graphite; go, golgi; $h$, haptonema; $l$, chrysose (leucosin); $m$, muciferous body; $m t$, mitochondrion; $n$, nucleus; $s$, scale.

Fig. 24. Individual swimming with flagella in the position characteristic for the species when swimming with the flagella behind the body. Narrow face of cell illustrated to show edges of the two chromatophores and the band of (what appears to be) large scales round the body.

Fig. 25. Cell anchored by haptonema-of which only the tip is visible and therefore the individual simulates a Prymnesium species; the body shows the thick circular band of scales with narrower bands from it to the non-flagellar pole.

Fig. 26. Individual coiling its flagella to stop body movement; two very young daughterflagella or two large elongated scales visible between parent-flagella.

Fig. 27. Early fission stage with four flagella; body broadened and compressed but second haptonema not yet formed.

Fig. 28. Late fission stage. 
very fine, smooth, apex gradually attenuated to a small knob (E.M. observation); the haptonema capable of attaching only by its distal swollen tip, thinner than the flagella, from I-I $\frac{1}{2}$ times body length when fully extended, with an internal structure of three concentric membranes surrounding a ring of seven fibres.

Four scale types present: large plates with upturned rims (average dimensions $\mathrm{I} \cdot 4 \times \mathrm{I} \cdot 2 \mu$ ), small plates with rims flexed towards outer surface and with two bulbosities near the centre on the outer side (average dimensions $0.8 \times$ $0.6 \mu$ ), about twice as numerous as the large plates, narrow elliptical plates with rim flattened against outer face (average dimensions $\mathrm{I} \cdot 2 \times 0.6 \mu$ ), less numerous than the large plates and probably present in a group near the flagellar pole, a few (I-3) large elliptical plates (average dimensions $2.5 \times 0.9 \mu$ ) with rims and a forked excrescence at one end, situated at the flagellar pole.

Chromatophores usually I or 2, not uncommonly 3 or 4 , deep goldenbrown, faintly striated on outer face, usually covering most of the periphery of larger cells but clear space sometimes showing in smaller cells, usually saucer-shaped to oblong, each with an internal pyrenoid. Lipid and chrysose (leucosin) produced. Ejectile muciferous bodies generally distributed in peripheral cytoplasm. Nutrition phototrophic and/or phagotrophic. Nontoxic to fish.

In motile phase asexual reproduction by fission into two daughter-cells, usually of equal size; other stages unknown.

Habitat: the sea at position lat. N. $50^{\circ} \mathrm{II}^{\prime}$, long. W. $04^{\circ} \mathrm{I}^{\prime}$ (II May I955, type culture) at surface. Type culture (Plymouth no. 136) deposited with the Culture Collection of Algae and Protozoa, Cambridge. The recorded distribution of Chrysochromulina polylepis is given in Table 2 (Appendix).

Cellula in statu erratico aliquantum metabola, plerumque ovalis, interdum subsphaerica, apice oblique truncata in foveam transversam depressa, 6-12 $\mu$ longa, 5-9 $\mu$ lata, cellulis majoribus manifesto compressis, in labium vel gibbam ad unum foveae latus productis. Flagella bina ex media fovea conferte orientia, subaequalia vel aequalia, rarissime manifesto inaequalia, homodynamica, cellula 2-3plo longiora, tenuissima, glabra, apice sensim attenuata, nodulo terminata; haptonema ibidem oriens, potestate haerendi solum in apice incrassato donatum, flagellis tenuius, extensum cellulae aequale vel sesqui longius, in sectione transversa tres membranas tubiformes concentricas ostendens fibras 7 in orbem dispositas induentes. Squamarum quattuor genera: magnae ( $\mathrm{I} \cdot 4 \mu \times \mathrm{I} \cdot 2 \mu$ diam.) margine in cingulum elevato cum reliqua parte rectum angulum formans; parvae (0.8 $\times 0.6 \mu$ diam.) cingulo marginali cum reliqua parte acutum angulum formante, medio in duas verrucas extrinsecus incrassatae; anguste ellipticae ( $\mathrm{I} \cdot 2 \times 0.6 \mu$ diam.) cingulo reliquae parti appresso, pauciores quam magnae, gregem ut videtur apicalem formantes; I-3 magnae ellipticae $(2.5 \times 0.9 \mu$ diam.) cingulo marginatae rectum angulum cum reliqua parte formante.

Chromatophora plerumque I vel 2, haud raro 3 vel 4 , saturate fulva, facie exteriore subtiliter striata, vulgo maximam partem superficiei majorum cellularum occupantia, 
sed in minoribus partem hyalinam interdum sinentia, plerumque catilliformia vel oblonga, pyrenoïde faciei interiori cuiusque apposito. Synthemata lipoïda et chrysosea (leucosinea). Corpora mucifera ejectilia plerumque in strato externo cytoplasmatis distributa.

Alga et phototropha et phagotropha seu alterutro solum victu alta; piscibus non venenosa.

Propagatio vegetativa in statu erratico bifissione effecta, cellulis filialibus plerumque aequalibus. Alii status ignoti.

Typus die II. Maji 1955 in summo mari lat. bor. $50^{\circ} \mathrm{II}^{\prime}$, long. occ. $04^{\circ} \mathrm{I} 3^{\prime \prime}$ lectus, in Plymouth Angliae sub numero 136 cultus, viva prole Vivario Cantabrigiensi tradita.

\section{SUMMARY}

A species of Chrysochromulina is described which habitually produces four different types of scale on one and the same cell. Scales are more opaque to electrons than in other recorded species of the genus and it has consequently been possible to trace something of their mode of production. They develop within vesicles inside the body and are subsequently deposited on the cell surface. The vesicles responsible are in a compact group beside the Golgi body and below the flagellar bases. Scale-production is at a maximum in the afternoon and greatly reduced or discontinued at night. A marked diurnal rhythm also affects other cell components, mitotic phases being abundant at 4.30 a.m. Some changes occurring in the Golgi body are described and discussed in a preliminary way.

\section{REFERENCES}

Manton, I., 1961. Some problems of mitochondrial growth. F. exp. Bot., Vol. 12, pp. $42 \mathrm{I}-9$.

Manton, I. \& Leedale, G. F., I96r $a$. Observations on the fine structure of Paraphysomonas vestita de Saedeleer, with special reference to the Golgi apparatus and the origin of scales. Phycologia, Vol. I, pp. 37-56.

- 196I $b$. Further observations on the fine structure of Chrysochromulina ericina Parke \& Manton. F. mar. biol. Ass. U.K., Vol. 4I, pp. I45-55.

- 1961 c. Further observations on the fine structure of Chrysochromulina kappa and Chrysochromulina minor with special reference to the pyrenoids. F. mar. biol. Ass. U.K., Vol. 4I, pp. 519-26.

MANTON, I. \& PARKe, M., I960. Further observations on small green flagellates with special reference to possible relatives of Chromulina pusilla Butcher. F. mar. biol. Ass. U.K., Vol. 39, pp. 275-98.

PARKE, M., I96I. Some remarks concerning the class Chrysophyceae. Brit. phycol. Bull., Vol. 2, pp. 47-55.

Parke, M., Lund, J. W. G. \& Manton, I., I962. Observations on the biology and fine structure of the type species of Chrysochromulina (C. parva Lackey) in the English Lake District. Arch. Mikrobiol., Bd. 42, pp. 333-52.

Parke, M., Manton, I. \& Clarke, B., I955. Studies on marine flagellates. II. Three new species of Chrysochromulina. F. mar. biol. Ass. U.K., Vol. 34, pp. 579-609.

- 1956. Studies on marine flagellates. III. Three further species of Chrysochromulina. F. mar. biol. Ass. U.K., Vol. 35, pp. 387-4I4. 
Parke, M., Manton, I. \& Clarke, B., 1958. Studies on marine flagellates. IV. Mrphology and microanatomy of a new species of Chrysochromulina. F. mar. biol. Ass. U.K., Vol. 37, pp. 209-28.

1959. Studies on marine flagellates. V. Morphology and microanatomy of Chrysochromulina strobilus sp.nov. F. mar. biol. Ass. U.K., Vol. 38, pp. 169-88.

\section{APPENDIX}

TABLE 2. RECORDED DISTRIBUTION OF CHRYSOCHROMULINA POLYLEPIS SP.NOV.

\section{Date}

II. v. 55

16. vii. 57

21. viii. 57

17. ix. 57

18. ii. 58

I5. iii. 58

16. iii. 58

I8. iii. 58

22. iv. $5^{8}$

20. v. 58

Io. vi. $5^{8}$

9. vii. 58

I. x. 58

13. i. 59

10. ii. 59

20. iv. 59

Io. vi. 59

II. viii. 59

8. ix. 59
Position

N. W.

$50^{\circ} \mathrm{II}^{\prime} \quad 4^{\circ} \mathrm{I3}^{\prime \star}$

$50^{\circ} 02^{\prime} \quad 4^{\circ} 22^{\prime}$

$50^{\circ} 02^{\prime} \quad 4^{\circ} 22^{\prime}$

$50^{\circ} 02^{\prime} \quad 04^{\circ} 22^{\prime}$

$50^{\circ} \mathrm{II}^{\prime} \quad 04^{\circ} \mathrm{I3}^{\prime}$

$50^{\circ} 02^{\prime} \quad 4^{\circ} 22^{\prime}$

$47^{\circ} 30^{\prime} \quad 7^{\circ} 18^{\prime}$

$47^{\circ} 20^{\prime} \quad 7^{\circ} 22^{\prime}$

$47^{\circ} 40^{\prime} \quad 07^{\circ} 13^{\prime}$

$47^{\circ} 46^{\prime} \quad 07^{\circ} 05^{\prime}$

$50^{\circ} 02^{\prime} \quad 04^{\circ} 22^{\prime}$

$50^{\circ} \mathrm{O2}^{\prime} \quad 4^{\circ} 22^{\prime}$

$50^{\circ} \mathrm{O2}^{\prime} \quad 4^{\circ} 22^{\prime}$

$50^{\circ} \mathrm{I}^{\prime} \quad \mathrm{O}^{\circ} \mathrm{II}^{\prime}$

$50^{\circ} 06^{\prime} \quad 4^{\circ} 2 I^{\prime}$

$50^{\circ} \mathrm{II}^{\prime} \quad 4^{\circ} 13^{\prime}$

$50^{\circ} 15^{\prime} \quad 04^{\circ} 13^{\prime}$

$50^{\circ} 02^{\prime} \quad 04^{\circ} 22^{\prime}$

$50^{\circ} 02^{\prime} \quad 04^{\circ} 22^{\prime}$

$50^{\circ} \mathrm{O2}^{\prime} \quad 4^{\circ} 22^{\prime}$

$50^{\circ} 1^{\prime} \quad 04^{\circ} \mathrm{II}^{\prime}$

$50^{\circ} 02^{\prime} \quad 04^{\circ} 22^{\prime}$

$50^{\circ} 02^{\prime} \quad 04^{\circ} 22^{\prime}$

$50^{\circ} 15^{\prime} \quad 04^{\circ} 13^{\prime}$

$50^{\circ} 02^{\prime} \quad 04^{\circ} 22^{\prime}$

$50^{\circ} \mathrm{II}^{\prime} \quad 04^{\circ} \mathrm{I3}^{\prime}$

$50^{\circ} \mathrm{Oz}^{\prime} \quad \mathrm{O}^{\circ} \mathrm{22}^{\prime}$

$50^{\circ} \mathrm{II}^{\prime} \quad 04^{\circ} \mathrm{I3}^{\prime}$

Depth

(m)

0.5

0.5

I0, 50

0.5

20

0.5

IO

$0.5,20$

20

IO, 20

5

0.5 , I0, 15

0.5

0.5

0.5

50

Io

20

0.5

$0.5,5,10,20$

20,50

0.5

5, 10, 20, 70

0.5
15
0.5
0.5

* Type culture strain of Chrysochromulina polylepis (Plymouth No. 136) isolated from this sample. 